\title{
Android Based Rural Decision Support Information System Model
}

\author{
Taufiq, Herman Mawenkang, M. Zarlis, Saib Suwilo
}

\begin{abstract}
The village needs to develop the independence and well-being of the community by improving knowledge, attitudes, skills, behavior, capacity, awareness, in utilizing resources through the determination of policies, programs, activities and mentoring that in accordance with the essence of the problem and the various priority needs of the villagers. The purpose of this research relates to the implementation of LAW Number 6 year 2014 Village, one of them about the potential information system Web-based integrated village to open information organization of Village governance to the public, the openness of public information so that citizens can be active together with the Government to build the village. Information is indispensable to know include: administration of the potential of the village, population administration, administration of research Objects, Village profile Village July Tambo Tanjong village, the village of Alue "Buya" Term Abeuk Budi with characteristic different Village, Research methods using Stochastic models and making the algorithm the Program so that the formation of a Database of android-based integrated Village by utilizing Cloud Computing and Mobile Computing, that makes it easier for users (community) in the to access the information in the respective decisions.. Models of decision support information systems Integrated Rural-based Android is the community to know how to make use of the existing resources for the activities of the noble mandate of appropriate $L A W$ village. Research results are very useful especially for researchers as knowledge and very benefit to Central Government, Government Tk. I, Government Tk. II, Government districts and especially in the reign of the village as well as society in General.
\end{abstract}

Keywords : Village, Android, Information, Decision Support.

\section{INTRODUCTION}

\subsection{Background}

Empowerment of village community as it is written in chapter I, article 1,ct No. 6 of the year 2014 of the village, is an effort to develop the independence and well-being of the community by improving knowledge, attitudes, skills, behaviour, ability, awareness, and make use of resources through the determination of policies, programs, activities and mentoring that fits with the essence of the problem and the priority needs of the villagers. Itt should take an active attitude of the village Government to prepare for any case related to the implementation of the ACT, one of which is

Revised Manuscript Received on October 15, 2019.

* Correspondence Author

Taufiq, USU \&camp.TI S3 Student and Lectures in Electrical Engenering. Malikusaleh University.

Herman Mawenkang, Faculty of Computer and IT Sciences, University of Sumatera Indonesia

M. Zarlis, Faculty of Computer and IT Sciences, University of Sumatera Indonesia

Saib Suwilo, Faculty of Computer and IT Sciences, University of Sumatera Indonesia

about a Village information system aims to unlock the holding of information governance governance the governance of the Village to the public, so the public is not being passive citizens who don't know anything about the conduct of the Government of the village, in contrast with the openness of public information citizens can more actively together with authorities to build the village. Village website is an investment for the community in order to have a useful added value with pemamfaatan internet technologies for all, through the information.

\subsection{Formulation of the problem}

Based on background uraian presented above, then be formulated several problems as follows:

1. How to plan a model integrated rural area information system by leveraging technology based on android Cloud Computing.

2. How to plan rural website in accordance with the laws of the Country No. 6 year 2014 about Rural Information System.

3. how the system for admitting foreign imformasi the Organization of a country side ,android, flexible with more Mobile Computing and Cloud Smart Computing.

4. How to plan a model help rural torpedo

\subsection{Scope of problem}

Based on the background description stated above, a number of problems can be formulated as follows:

1. How to design an integrated rural information system model based on Android by utilizing Cloud Computing technology.

2. How to design a Village website in accordance with the Village Law number 6 of 2014 concerning the Village information system.

3. How to implement the rural management information system

4. How to implement a rural management Information system based on Android, which is flexible with Mobile Computing and Cloud Computing devices. 2. How to design an integrated village information model

\subsection{Special purpose and urgency (primacy of Research)}

Based on the identification of the problem above, then the specific purpose and urgency (primacy) of this research are:

1. Encourage public participation in the planning of the construction of the village kept in a transparent, easy and versatile (Mobile Computing) 
2. Compose the village development planning in accordance with the priorities and potential the value of local wisdom. 3. Encourage public participation in the policy formulation of the village done through the deliberations of the village.

4. This research will assist the Agency in the development of model systems information management the village independently Z1 Android-based, integrated

\subsection{The urgency priority review.}

In general the urgency (virtue) this research is a model of the design of information systems of each of the following areas: the potential of the village, the village of bureaucracy (the decision), the village, eventually forming a database integrated Village-based android with Cloud Computing and Mobile Computing devices. The existence of a model of the information system of the village so Village government system be transparent in all areas and can be accessed by all communities in need. The results of this research are also very useful especially for the research team consists of as knowledge and also very bermamfaat to Central Government, Government Tk. I, Government Tk. II, Government districts and in particular in the administration of the village and the community need information.

\section{The Findings Of The Innovation That Is Targeted And Its Application}

Research on the Model of information systems decision support Android-based Integrated Rural information potential of the village, the village of bureaucratic information system (decision), the information system on population data of the village, the village of geographic information use the application Google Earth/Google Map of the village that makes it easier for users (community) in accessing information of each Village are already based website and the innovations developed this android-based systems, Mobile Computing, Cloud Computing and integrated data Model dipedesaan. And finally the existence of mathematical model formulation in decision-making potential rural integrated.

\section{REVIEW OF LITERATURE}

\subsection{The Village}

Law number 6 Year 2014 about village, confirmed that the village was the spearhead of the lowest Government that has set the development of autonomy for their people to prosper. Village Development the village under law aimed at improving the welfare of the village community and quality of life of mankind as well as poverty reduction through the provision of basic needs fulfillment, construction of infrastructure, development of the potential the local economy, as well as the utilization of natural resources and the environment in a sustainable way. And the public can use mathematical models to take the decision to see a potential areas (villages) that are already integrated into the web-based information systems utilizing the android and mobile computing. Mathematical model of stochastic models and here is the linear programing.

\subsection{Strategic Issues Related To The Potential of An Integrated Village}

The issue - conveniently located in the village of LAW issues with regard to development, finances, assets, governance, rural area development, cooperation between the village and the Village's community agencies. This can be illustrated in the following scheme:

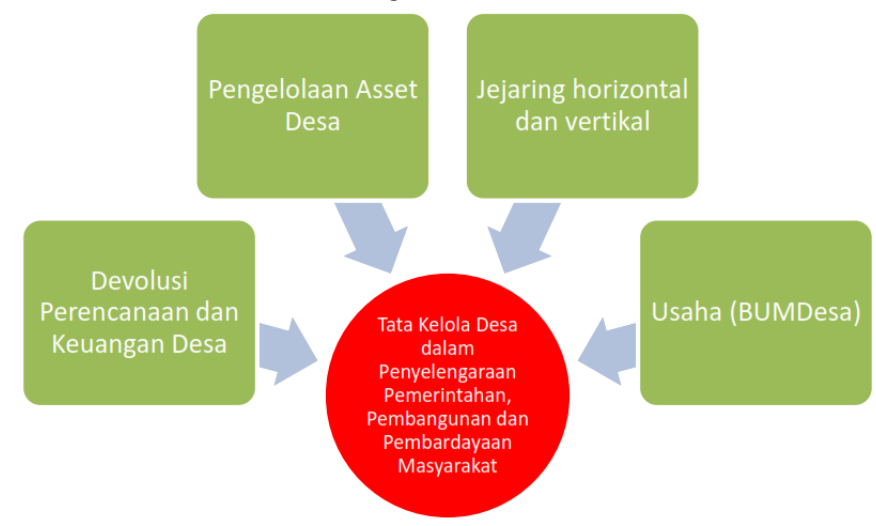

Figure 1: Components Supporting Self-reliance Village In Service, Development And Empowerment

(Source: Budiman Sujatmiko's strategic issues, the PARLIAMENT faction of PDI-P)

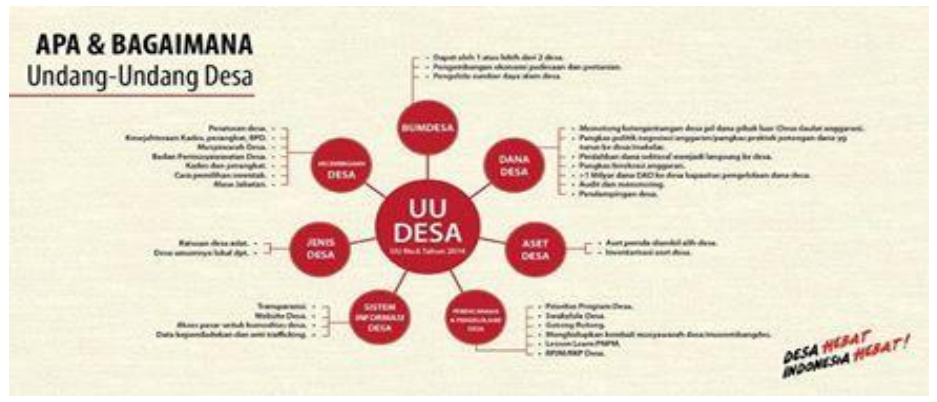

Figure 2: The Design Of The Institutional Basis Of Village Governance

(Source www.Siagam.web.id)

\subsection{System}

In the design of a system of information directed to the pemamfaatan technology to the maximum which is composed of some elements or components that make up the network and has a goal to be achieved. Definition of system according to Jogiyanto $\mathrm{H}$. M in his analysis and Design States that: "the system is a collection of elements that interact to accomplish a specific goal." (2005:2).

\subsection{Information Systems}

According to Sidharta (1995:11), "an information system is a man-made system that contains a set of integrated components of manual and computerised components that aim to collect data, process data, and information for users ".

\subsection{Understanding The Database}

The database is a set of interconnected data file and organize in such a way that makes it easy to receive and process data. The database system environment emphasizing data that does not depend (independent) in applications that will use data (Andi, 2006). 


\subsection{Android}

The operating system is a Linux-based (open source) that is used for smartphones and tablet computers. Android provides an open platform for developers to create their own applications required by the various mobile device. Initially Google Inc. bought Android Inc. newcomers that makes software for cell phones. Then to develop Android, an Open Handset Alliance, a consortium of 34 corporations hardware, software, and telecommunications, including Google, HTC, Intel, Motorola, Qualcomm, T-Mobile, and Nvidia. Source (http://pusatteknologi.com/android-adalah.html)Sistem operasi yang berbasis yang Linux (open source Google, HTC, Intel, Motorola, Qualcomm, T-Mobile, dan Nvidia. Sumber (http://pusatteknologi.com/android-adalah.html)

\subsection{Mobile Computing}

Understanding of Mobile computing is the ability to deal with technology transfer/human movement in computer use practically. Some understanding about mobile computing include::

1. Mobile computing is a new paradigm of technology that is capable of do communications although the user doing the transfer.

2. Is the advancement of computer technology, often referred to as mobile computer (portable computer) that can communicate with the network without cable (wireless).

3 . Is the set of equipment (hardware), data, and software Bermobilisasi/application switch location.

4. Is a particular class where the system of Distributing some of the nodes can be escape from the disturbs operation, move freely, and can make connections back on different networks.

This definition can understood why we need mobile computing. The key word is we humans are constantly moving, dynamic and evolving from one State to another. So need a device that is capable of following the movements of the US. Source (http://worldnews-online-worldpedia)

\subsection{Cloud Computing}

The definition of Cloud Computing (cloud computing) is a combined utilization of computer technology (computing) in a network with the development of the cloud (cloud) which has the function to run a program or application via a computer - computers that are connected at the same time, but not all of the terkonekasi over the internet using cloud computing. Computer technology-based system this Cloud is a technology that makes the internet as the central server to manage data and user applications as well. This technology allows the user to run the program without installation and allow users to access their personal data via a computer with internet access. Source: (http://pusatteknologi.com/pengertian-manfaat-cara-kerja-d an-contoh-cloud-computing.html)

\subsection{Decision Support Models}

Decision support model consists of:

1. Mathematical models.

2. The Database.

3. Software.
Decision support software is often referred to by DSS generator. DSS generator contains modules for database, model and dialogue management. The database module provides several things, such as: creation, interrogation and maintenance for the DSS database. DSS databases have the ability to find a database system that has been saved. While the model module used to present the ability to create, maintain and manipulate mathematical models into shape. This basic model featuring electronic spreadsheet. Model dialog used to entice users to connect directly between users with computers in the search for solutions.

Many problems of practical decisions in particular, is a rather complex can modeled as a linear program.

$$
\begin{gathered}
\min \left\{c_{1} x_{1}+c_{2} x_{2}+\cdots+c_{n} x_{n}\right\} \\
\text { Subject } \\
a_{11} x_{1}+a_{12} x_{2}+\cdots+a_{1 n} x_{n}=b_{1} \\
a_{21} x_{1}+a_{22} x_{2}+\cdots+a_{2 n} x_{n}=b_{2} \\
a_{m 1} x_{1}+a_{m} x_{2}+\cdots+a_{m n} x_{n}=b_{m} \\
a_{m 1} x_{1}+a_{m} 2 x_{2}+\cdots+a_{m n} x_{n}=b_{m}
\end{gathered}
$$

Using the vector metrics with the notation then formulation problems:

$$
\begin{gathered}
\min c^{\mathbf{T}} x \\
\text { s.t. } A x=b \quad x \geq 0
\end{gathered}
$$

\begin{tabular}{|c|c|c|}
\hline No & $\begin{array}{l}\text { Activity } \\
\text { step }\end{array}$ & Description of activities \\
\hline 1 & Step I & $\begin{array}{l}\text { Survey / observation to research location: } \\
\text { Find problems at the location } \\
\text { (related to village information system } \\
\text { issues) }\end{array}$ \\
\hline 2 & StepII & $\begin{array}{l}\text { Determine the subject matter: } \\
\text { a. The subject matter is obtained from the } \\
\text { survey results to the location. } \\
\text { b. Determination of the subject matter } \\
\text { involves the entire team membership. }\end{array}$ \\
\hline 3 & Step III & $\begin{array}{l}\text { Determine the purpose of the activity: } \\
\text { The purpose of the activity is adjusted to } \\
\text { the subject matter described in the } \\
\text { background }\end{array}$ \\
\hline 4 & Step IV & $\begin{array}{l}\text { Study of literature: } \\
\text { a. Looking for literature studies / library } \\
\text { books that are relevant to the topic of the } \\
\text { problem. } \\
\text { b. Search for scientific research / journals } \\
\text { relevant to the topic of the problem. } \\
\text { c. Looking for library references via the } \\
\text { internet. }\end{array}$ \\
\hline
\end{tabular}

\section{RESEARCH METHODS}

\subsection{Description of the activities carried out}

Stages that is done on the research Model of information systems decision support Integrated Rural-based Android on Table 1

Table 1: Description of activities that will be carried 


\begin{tabular}{|c|c|c|}
\hline 5 & Step V & $\begin{array}{l}\text { Data collection: } \\
\text { a. The data obtained are primary and } \\
\text { secondary data. } \\
\text { b. Primary Data is the data obtained } \\
\text { directly from the research location } \\
\text { through interviews, documentation and } \\
\text { direct observations such as ID card data, } \\
\text { family card data, birth certificate data, } \\
\text { population displacement data, mortality } \\
\text { data, village financial data, village RPJM } \\
\text { data, village financial reports, } \\
\text { performance reports village development } \\
\text { (LKP), Village potential data, Village } \\
\text { mailing administrative data and others. } \\
\text { c. Secondary data is data obtained } \\
\text { indirectly to information through } \\
\text { literatures and information sourced from } \\
\text { outside the village. }\end{array}$ \\
\hline 6 & StepVI & $\begin{array}{l}\text { Data processing } \\
\text { Make system applications in } \\
\text { Telecommunications and Informatics } \\
\text { engineering laboratories and implement } \\
\text { them at } \\
\text { (www.Siagam.web.id) }\end{array}$ \\
\hline 7 & StepVII & $\begin{array}{l}\text { Designing a Mathematical Model } \\
\text { a. Make a model with Stochastic } \\
\text { b. Creating a Program Algorithm }\end{array}$ \\
\hline
\end{tabular}

The research begins with observing the location of the research objects, namely Juli Tambotanjong Village, July District, Bireun Regency with the village website www.julitambotanjong.desa.id and Alue Buya Village Term District, Bireun Regency with the name of the village website www.Aluebuya.desa.id, and Abeuk Village Budi in July District.

\subsection{Flow chart Research}

The research began by conducting a survey to the location for collecting initial data, especially the village administration data. The data that obtained by analyzed and sorted to determine the variables that correspond to each type of village administration as mentioned in the background of the problem in order to achieve the research objectives, more details can be seen in the following research flowchart:

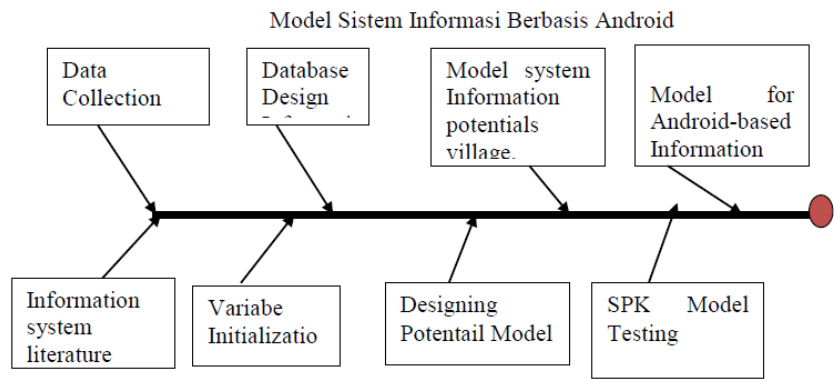

Figure 3: Research Flow Chart

\subsection{Model Review Of The Decision.}

This is complete with external scrutiny, among others:

The availability of integrated country Database, integrated information system Model of each Data Data anti Rural, Rustic, State administration of traffiking Data
Administration with correspondence and Data Administration with Rural Expeditions, Population, Rural geographical segment Data State administration of Assets, Data, Data Administration with Potential Rural rural Rural Profile Data and rural Website documentation literature search results.

Many problems of the practice results in particular, relatively complex could modeled as a linear program.

$$
\begin{aligned}
& \min \left\{c_{1} x_{1}+c_{2} x_{2}+\cdots+c_{n} x_{n}\right\} \\
& \text { Subject } \\
& \qquad \begin{array}{l}
a_{11} x_{1}+a_{12} x_{2}+\cdots+a_{1 n} x_{n}=b_{1} \\
a_{21} x_{1}+a_{22} x_{2}+\cdots+a_{2 n} x_{n}=b_{2} \\
a_{m 1} x_{1}+a_{m 2} x_{2}+\cdots+a_{m n} x_{n}=
\end{array}
\end{aligned}
$$

$b_{m}$

$$
a_{m 1} x_{1}+a_{m 2} x_{2}+\cdots+a_{m n} x_{n}=
$$

$b_{m}$

$$
\text { Using vector matrix notation then formulation }
$$

problems as follows:

$\min c^{\mathbf{T}} x \quad$ s.t. $A x=b \quad x \geq 0$

\subsection{The Model Village}

In this study used desaku function (Heady and Dillon, 1964) that the mathematical formula $\neg$ is: $Y i=a$ Xijb. eijD.u, Yi: crop production to $\mathrm{i}$; a: intersep, konstante; $\mathrm{b}$ : regression coefficient; XI: the free variables, the means of production; D: variable change password; e: exponential,

\subsection{The Population Model}

This model is of three kinds of submodel, namely population forecasting model (Eriyatno and Siswanto, 1989), the model estimates the availability of agricultural potential, and laham model calculations needs a minimum population for workers.

\subsection{Location Research}

This research was conducted in Bireun District at July Tambotanjong, the village of Abeukbudi. It is Tambotanjong Jul village at located on the outskirts of Abeuk budi and the Village is located while Urban an inland village of Aluebuya, the village is located in district of Term which is the coastal areas, Government Agencies (Agency Village Empowerment) and testing is performed in the laboratory of Informatics Engineering Faculty of engineering Unimal. The indicators Measured close to the formation of an integrated database comprising

1 Administrative Data on Population.

2. Geographic Data Village

3. Data of the administration of the assets of the village

4. Administrative Data on the potential of the village

5. Profile Data Village

6. Village Website 


\section{THE RESEARCH OF INFORMATION DECISION SUPPORT INTEGRATED RURAL}

Models of decision support information systems integrated Village is a computer application or software that used to specifically enhance public services, Government Affairs, financial affairs, affairs development, civic affairs and Affairs other social in the village-based computer technology. Development and manufacture of a decision support system is part of the implementation of the regulations of the CONSTITUTION of the village 06/2014 number of financial report preparation guidelines and utilization profile data village.

Information system contains a variety of data and information that is very important for the Government, villagers and for all stakeholders associated with the village, which is very useful for the village in providing fast service, cheap and accurate against society and against the all village of stakeholders. With the presence of Government, information systems of each village can be detailed and systematic plan. Not only the provincial government and municipalities, but also the communities can access the information system directly.

\section{Display research results}

Based on the research of the model of information systems decision support Integrated Rural-based android obtained the following display models, be it web-shaped profile (android), the profile of the potential of the village, population and financial profile integrated into the information system.

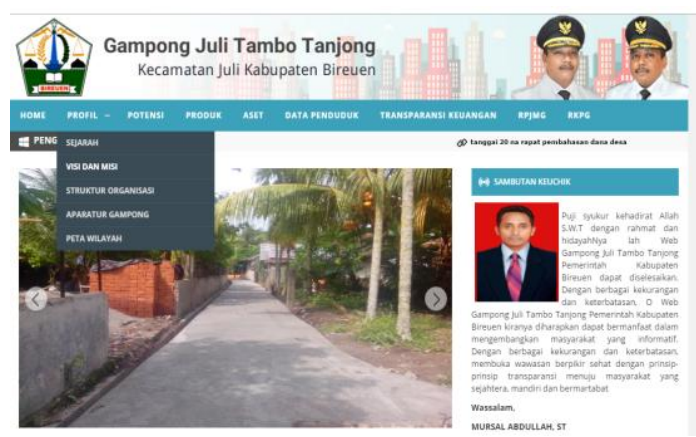

Figure 4: profile view Village

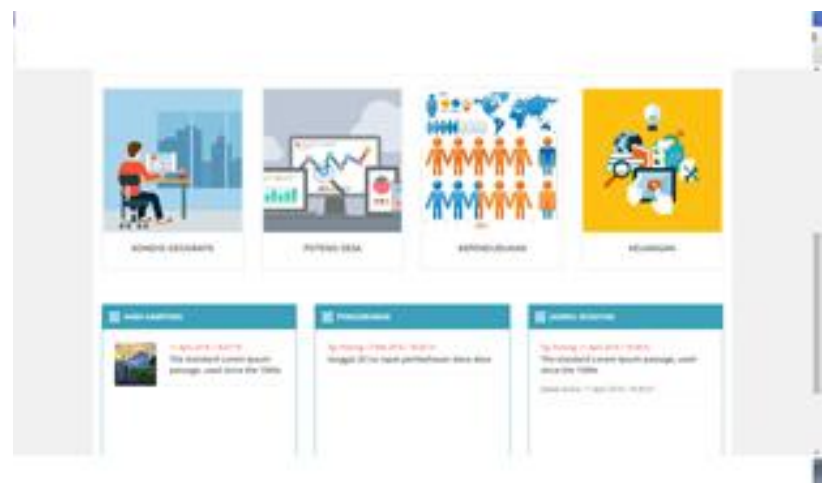

Figure 5: Profile Potential Village

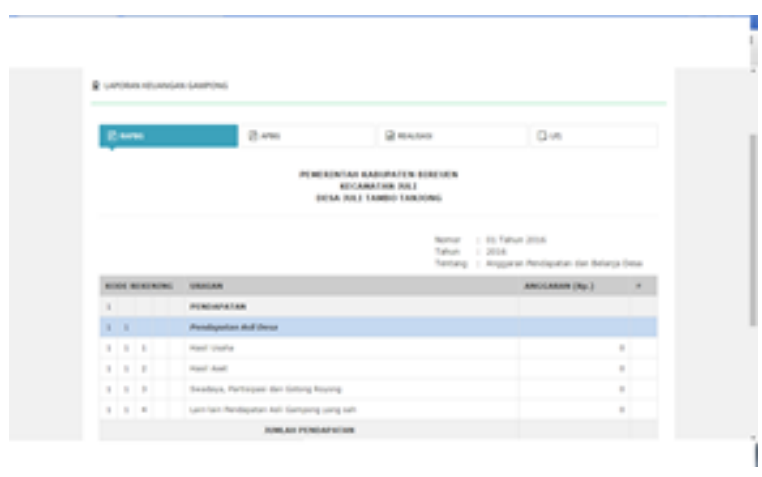

Figure 6: Village financial system

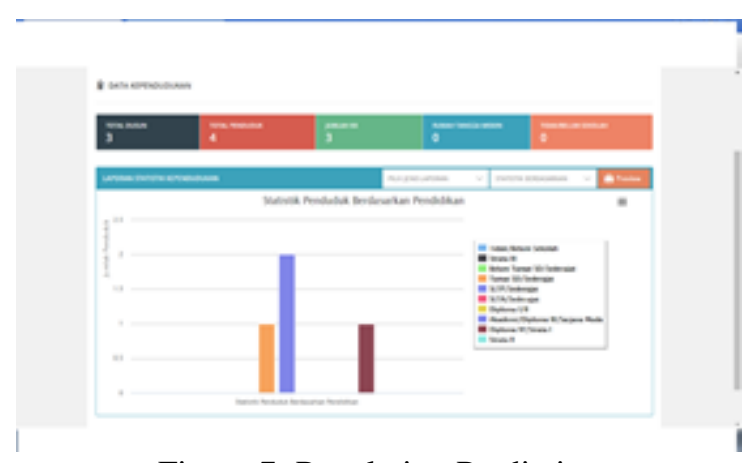

Figure 7: Population Prediction

\section{CONCLUSION AND SUGGESTIONS}

The conclusion of the results of the research of the Model of information systems decision support Integrated Rural-based Android was as follows:

1. Model, which implicated shaped online because of the android-based web way village must have hosting and domain of each village.

2. Mathematical models included the time of completion, residents of the village of potential profiles, to determine the human resources.

3. The Model used is linear programming because the data entered is always incremented every time there is a change.

\section{SUGGESTIONS}

Fore in models of information systems decision support Android-based Integrated Country there should be a complete let me complete the information shown and can be real time.

\section{REFERENCES}

1. EfrainTurban, Ramesh Sharda, DursunDelen, Ancillary Systems Decision And Information Executives. translated BayuIndrayana graduate school of 2013. IPB, Bogor

2. Nasendi, B. D. and a. Anwar. 1985. A Linear Program and Varia $\neg$ sinya. Pt. Gramedia, Jakarta.

3. Richard. 2003. Management (management). Salemba Jakarta: Four.

4. SOEMARNO. 1991b. The study of land use Allocation Model which is Environmentally in DAW Selorejo. National Science Congress V. 3-7, Jakarta, September 1991.

5. Siagian, Sondang. 1990. The theory and practice of decision making. Jakarta: Haji Masagung.

6. Shaparev, n., Yakubalik, o. 2016. Usage of web mapping systems and service for information support of regional management. MATEC Web of Conferences 79, 01081 